\title{
Evaluation of Clinical and Laboratory Findings of Children Who Have Had Hepatitis A Virus Infection
}

\author{
Hepatit A Virüsü Enfeksiyonu Geçiren Çocukların Klinik ve \\ Laboratuvar Bulgularının Değerlendirilmesi
}

\author{
Uğur Deveci'(iD), Ufuk Acar²(iD), Enes Salı3(iD) \\ ${ }^{1}$ Division of Pediatric Gastroenterology, Department of Pediatrics, FIrat University School of Medicine, Elazığ, Turkey \\ ${ }^{2}$ Infectious Diseases Unit, Suruc Directorate of Health, Şanlıurfa, Turkey \\ ${ }^{3}$ Clinic of Pediatric Infectious Diseases, Umraniye Training and Research Hospital, Istanbul, Turkey
}

Cite this article as: Deveci U, Acar U, Salı E. Evaluation of clinical and laboratory findings of children who have had hepatitis A virus infection. J Pediatr Inf 2021;15(1):e12-e18.

Abstract

Objective: Hepatitis A virus (HAV) infection is a common disease in the community and can cause significant morbidity and mortality in older ages. This study to investigate and discuss the clinical and laboratory findings, treatment and prognosis of children with acute viral hepatitis $A$ in our hospital.

Material and Methods: Clinical and laboratory findings of 105 children diagnosed with acute HAV infection between January 2017 and December 2017 in Şanlıurfa Training and Research Hospital, south-east Turkey, were examined.

Results: $54.3 \%(n=57)$ of the patients were males, and mean age was 6.7 \pm 3.4 years (range: $1-17$ years). $65.7 \%$ of the patients were Syrian refugees, and most of the cases were admitted in winter and autumn months. The most common symptoms were jaundice (93.3\%), fatigue (76.2\%), fever (67.6\%), anorexia (66.6\%) and abdominal pain (57.1\%). Serum AST, ALT, ALP, GGT, total bilirubin and direct bilirubin levels were high in all patients. Hematologic abnormalities and acute liver failure occurred in $53.4 \%$ and $3.8 \%$ of the cases, respectively. Two patients (1.9\%) had gallbladder hydrops, one patient $(0.9 \%)$ had reactive arthritis and one patient $(0.9 \%)$ had autoimmune hepatitis. Overall mortality rate was $0.9 \%$.

Conclusion: HAV infection is still an important public health problem in our country. The disease ranges from mild clinical course to complicated cases such as acute liver failure. Improving environmental conditions along with immunization and educating the public on hygiene are very important in disease prevention.

Keywords: Hepatitis A virus, childhood, clinical, laboratory, acute liver failure
Öz

Giriş: Hepatit A virüs (HAV) enfeksiyonu, sık görülen, özellikle ileri yaşlarda morbidite ve mortalite nedeni olabilen önemli bir enfeksiyondur. Bu çalışmada, HAV enfeksiyonu tanısı almış çocukların klinik ve laboratuvar özelliklerinin tanımlanması amaçlandı.

Gereç ve Yöntemler: Şanlıurfa Eğitim ve Araştırma Hastanesi'nde Ocak 2017 ile Aralık 2017 tarihleri akut HAV enfeksiyonu tanısı konulan 105 çocuk olgunun klinik ve laboratuvar özellikleri incelenmiştir.

Bulgular: Hastaların \%54.3'ü ( $n=57)$ erkek olup yaş ortalaması $6.7 \pm 3.4$ yıl (sınır: 1-17 yıl) bulundu. Hastaların \%65.7'si Suriyeli sığınmacılardan oluşmaktaydı ve olguların en sık kış ve sonbahar aylarında başvurduğu saptandı. En sık yakınmaların sarılık (\%93.3), halsizlik (\%76.2), ateş (\%67.6), iştahsızlık (\%66.6) ve karın ağrısı (\%57.1) olduğu belirlendi. OIguların tamamında serum ALT, AST, ALP, GGT, total bilirubin ve direkt bilirubin düzeylerinde yükseklik gözlendi. Olguların \%53.4'ünde hematolojik anormallikler, \%3.8'sinde ise akut karaciğer yetmezliği eşlik etmişti. Iki hastada (\%1.9) safra kesesi hidropsu, bir hastada (\%0.9) reaktif artrit ve bir hastada ise (\%0.9) otoimmün hepatit gelişmişti. Genel olarak mortalite oranı $\% 0.9$ idi.

Sonuç: Dünya ve ülkemizde akut HAV enfeksiyonu ciddi bir toplum sağıı̆ı sorunu olmaya devam etmektedir. Hastalık klinik seyri hafif formdan akut karaciğer yetmezliği gibi komplike vakalara kadar değiş̧ebilmektedir. Hastalıktan korunmada bağışıklama ile birlikte çevre koşullarının iyileştirilmesi ve hijyen konusunda halkın eğitilmesi çok önemlidir.

Anahtar Kelimeler: Hepatit A virüsü, çocukluk çağı, klinik, laboratuvar, akut karaciğer yetmezliği

Correspondence Address/Yazışma Adresi

Enes Salı

Ümraniye Eğitim ve Araştırma Hastanesi,

Çocuk Enfeksiyon Hastalıkları Kliniği,

İstanbul-Türkiye

E-mail: ugurdeveci23@hotmail.com 


\section{Introduction}

Hepatitis A virus (HAV), which is a member of the Picornaviridae family, leads to acute liver infections. Although it is widely seen throughout the world, it continues to be a serious public health problem in undeveloped and developing countries in particular. HAV infections, which are highly contagious, are usually seen in autumn and winter. The basic routes of infection are fecal-oral routes through contaminated food or water (1).

The infection can cause different clinical pictures from an asymptomatic condition to fulminating hepatitis, but is not seen as a chronic condition. Although HAV can infect tissues other than the liver, the majority of clinical findings emerge as a result of liver inflammation. The World Health Organization (WHO) reported that HAV infection was responsible for approximately 11.000 deaths worldwide in 2015 . It has been reported that HAV infection is responsible for $0.8 \%$ of all mortality associated with viral hepatitis (2).

Turkey is classified as a moderately endemic region for HAV infection (3). With effect from November 1, 2012, hepatitis A vaccine administered as 2 doses at 18 months and 24 months was added to the routine vaccination schedule by the Turkish Ministry of Health. In addition to this, with improvements in hygiene and environmental conditions in recent years, it has been reported that there is a $50 \%$ reduction in hepatitis A cases (4). However, HAV infection in adults, resulting from a shift in contact to older ages, leads to severe clinical tables such as fulminating hepatitis at a rate of $10 \%-15 \%$ (5).

The majority of publications related to HAV infection have been studies of local seroprevalence. There are few studies evaluating the epidemiological, clinical and laboratory data of patients (6-10). The aim of the current study was to investigate the demographic, clinical and laboratory data of cases diagnosed with acute HAV infection in Şanlıurfa Training and Research Hospital.

\section{Materials and Methods}

In this study, evaluation was made of the clinical and laboratory data of 105 pediatric patients diagnosed with acute HAV infection between January 2017 and December 2017 in Şanlıurfa Training and Research Hospital, South-East Turkey. The patients were separated into 3 age groups of 1-5 years, 6-12 years and $>12$ years, and they were also evaluated as pre-school-age and school-age. Two case groups were also formed of those who were and were not citizens of the Turkish Republic.

Age and sex of the patients were recorded and seasonal distribution, status and duration of hospital stay were examined. The most frequently seen clinical symptoms and findings of the patients were evaluated. From laboratory tests, data were examined of white blood cells (WBC), and thrombocyte count, hemoglobin level, and as markers of liver damage, the alanine aminotransferase (ALT), aspartate aminotransferase (AST), alka- line phosphatase (ALP), gamma-glutamyl transpeptidase (GGT) levels, total and direct bilirubin, total protein and albumin together with prothrombin time (PT) and INR (international normalized ratio) results. Serum transaminase levels elevated 20100-fold of normal were accepted as hepatitis (11). In order to confirm the diagnosis, anti-HAV immunoglobulin (lg) M and anti-HAV IgG positivity were investigated with serological methods. The diagnosis of acute viral hepatitis A infection was made from anti-HAV IgM positivity, which is a marker of HAV infection, together with the presence of clinical symptoms and findings.

Acute liver failure was established according to the following criteria: i) An acute-onset liver disease with no indication of chronic liver disease, ii) biochemical and / or clinical signs of severe liver dysfunction (prothrombin time-PT $>20$ seconds (sec) "international normalized ratio" INR> 2, Vitamin K support is not improved). If PT is 15-19.9 seconds or INR 1.5-1.9, the presence of hepatic encephalopathy is sought. If PT> 20 sec and INR> 2, encephalopathy is not sought (12).

Data obtained in the study were analyzed statistically using SPSS version 20.0 for Windows. According to the characteristics of the variables, percentages, mean values and the Chi-square test were used in statistical evaluations. Continuous variables were stated as mean \pm standard deviation and median (minimum-maximum) values, and categorical variables as number $(n)$ and percentage (\%). A value of $p<0.05$ was accepted as statistically significant.

\section{Results}

The 105 cases evaluated in this study comprised $54.3 \%$ $(n=57)$ males, $65.7 \%$ Syrian refugees and $38.1 \%(n=40)$ were of pre-school-age (1-5 years) (Table 1$)$. The patients presented mostly in the winter months (51.4\%), followed by autumn

Table 1. Demographic characteristics of the cases

\begin{tabular}{|l|c|c|}
\hline Demographic Characteristics & $\mathbf{n}$ & $\%$ \\
\hline Gender & & \\
Male & 57 & 54.3 \\
Female & 48 & 45.7 \\
\hline Age groups & 40 & \\
1-5 years & 56 & 38.1 \\
6-11 years & 9 & 83.3 \\
12-17 years & & \\
\hline Nationality & 36 & 34.3 \\
Republic of Turkey & 69 & 65.7 \\
Syria (refugee) & & \\
\hline Age groups of nationality & 3 & 2.9 \\
1-5 years of Turkish patients & 26 & 24.8 \\
6-11 years of Turkish patients & 7 & 6.7 \\
12-17 years of Turkish patients & & \\
\hline Age groups of nationality & 37 & 35.2 \\
1-5 years of Syria (refugee) patients & 30 & 28.6 \\
6-11 years of Syria (refugee) patients & 2 & 1.9 \\
12-17 years of Syria (refugee) patients & \\
\hline
\end{tabular}




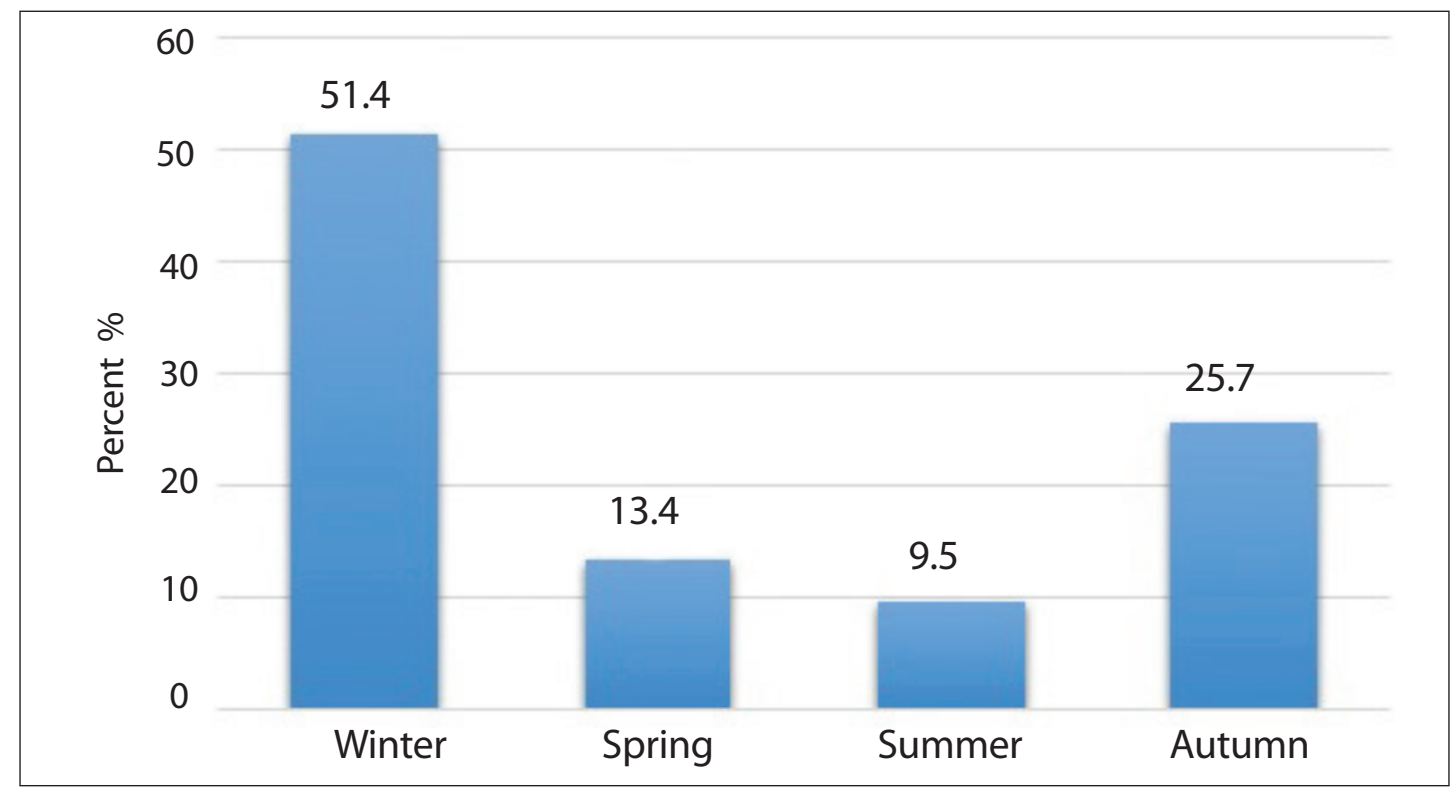

Figure 1. Seasonal distribution of the cases.

(25.7\%), spring (13.3\%) and summer (9.5\%) (Figure 1). Mean age of the whole patient group was $6.7 \pm 3.4$ years (range, $1-17$ years); girls: $6.7 \pm 3.5$ years and boys: $6.7 \pm 3.3$ years ( $p>0.05$ ).

The complaints of the patients on presentation were determined as jaundice (93.3\%), listlessness (76.2\%), fever (67.6\%), anorexia (66.6\%) and abdominal pain (57.1\%) (Table 2). No significant difference was determined between the age groups in respect of complaints on presentation ( $p>0.05$ ). Serum ALT, AST, ALP, GGT, total bilirubin and direct bilirubin levels were found to be high in the patients. Mean serum total bilirubin level was 5.1 $\pm 3.4 \mathrm{mg} / \mathrm{dl}$ (range, $0.24-17 \mathrm{mg} / \mathrm{dl}$ ) and direct bilirubin level was $4.3 \pm 2.9 \mathrm{mg} / \mathrm{dl}$ (range, $0.12-14 \mathrm{mg} / \mathrm{dl}$ ) (Table 3). Low levels of albumin were determined in $39 \%$ ( $n: 41$ ) of cases and low total protein in $21 \%(n=22)$. PT was prolonged in $34.3 \%(n=36)$ of the patients, and an increase in INR (range, 0.8-2.4) was determined in $29.5 \%$. Of the patients determined with prolonged PT-INR, Vitamin K was administered to approximately one third.

Mean leukocyte count was $8292 \pm 2701 / \mathrm{mm}^{3}$ (range, 3890$16240 / \mathrm{mm}^{3}$ ) with leukocytosis $\left(\mathrm{WBC}>10.200 / \mathrm{mm}^{3}\right.$ ) deter-

Table 2. The frequency of the symptoms seen in patients

\begin{tabular}{|l|c|c|}
\hline & $\mathbf{n}$ & $\%$ \\
\hline Jaundice & 98 & 93.3 \\
\hline Listlessness & 80 & 76.2 \\
\hline Fever & 71 & 67.6 \\
\hline Anorexia & 70 & 66.6 \\
\hline Abdominal pain & 60 & 57.1 \\
\hline Nausea & 59 & 56.2 \\
\hline Vomiting & 49 & 46.7 \\
\hline Diarrhea & 12 & 11.4 \\
\hline
\end{tabular}

mined in 24 (22.9\%) cases, leukopenia (WBC $<4600 / \mathrm{mm}^{3}$ ) in 2 $(1.9 \%)$, low hemoglobin in $4(3.8 \%)$, and thrombocytopenia in $3(2.9 \%)$ (Table 3). All patients were determined with anti-HAV IgM positivity and 102 with anti-HAV IgG positivity. Of these patients, $43(41 \%)$ were hospitalized for treatment. Mean length of hospital stay was $3.73 \pm 1.58$ days (range: $1-17$ days). Gallbladder hydrops developed in $2(1.9 \%)$ patients, reactive arthritis in $1(0.9 \%)$, and autoimmune hepatitis in $1(0.9 \%)$. Four (3.8\%) patients with progressive acute liver failure were transferred to the liver transplantation center. Despite all treatments and interventions applied in the liver transplantation center, one of these patients was exitus before transplantation could be performed. Mortality rate was determined as $0.9 \%$. The other 3 patients who were transferred to the liver transplantation center were applied with supportive treatment and plasmapheresis. These patients responded to the supportive treatment, and liver transplantation was not performed. In the subsequent follow-up period, autoimmune hepatitis developed in one of these patients and no problems developed in the long-term follow-up of the other two patients.

\section{Discussion}

The results of this study showed that more than half of the cases of HAV infections encountered in this study region were unvaccinated children who had arrived through irregular migration as a result of armed conflicts.

In cases developing acute HAV infection, early diagnosis, follow-up and observation in respect of fulminating liver failure are required and in cases that develop fulminating liver failure, transfer to a liver transplantation center is mandatory.

It has been reported that in an outbreak of hepatitis $A$ seen in the state of California in the USA, in 2017, 650 cases were 
Table 3. Laboratory test values on presentation

\begin{tabular}{|c|c|c|}
\hline \multicolumn{3}{|l|}{ Biochemical values } \\
\hline & Mean \pm SD & (min-max) \\
\hline AST (U/L) & $887.0 \pm 709.7$ & $95-3010$ \\
\hline ALT (U/L) & $1005.4 \pm 1057.1$ & $104-9424$ \\
\hline ALP (U/L) & $406.8 \pm 146.4$ & 129-1037 \\
\hline GGT (U/L) & $193.3 \pm 105.8$ & $65-555$ \\
\hline Direct bilirubin (mg/dl) & $4.3 \pm 2.9$ & $0.12-14$ \\
\hline Total bilirubin (mg/dl) & $5.1 \pm 3.4$ & $0.24-17$ \\
\hline Albumin (g/dl) & $3.6 \pm 0.6$ & $1.5-5$ \\
\hline Total protein (g/dl) & $7.1 \pm 0.8$ & $5-9.4$ \\
\hline Prothrombin time (secs) & $13.7 \pm 2.8$ & $9.3-26.2$ \\
\hline INR & $1.1 \pm 0.25$ & $0.8-2.4$ \\
\hline Anti-HAV IgM & $10.6 \pm 3.0$ & $1.6-20$ \\
\hline Anti-HAV IgG & $54.1 \pm 17.3$ & $0-60$ \\
\hline \multicolumn{3}{|l|}{ Hematological values } \\
\hline & $\mathrm{n}$ & $\%$ \\
\hline \multicolumn{3}{|l|}{ White blood cells $\left(\times 10^{3} / \mu \mathrm{L}\right)$} \\
\hline$<4.6$ & 2 & 1.9 \\
\hline $4.6-10.2$ & 79 & 75.2 \\
\hline$>10.2$ & 24 & 22.9 \\
\hline \multicolumn{3}{|l|}{ Hemoglobin (g/dl) } \\
\hline$<9.5$ & 4 & 3.8 \\
\hline $9.5-15.5$ & 95 & 90.5 \\
\hline$>15.5$ & 6 & 5.7 \\
\hline \multicolumn{3}{|l|}{ 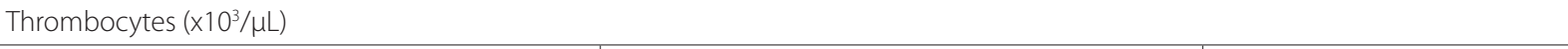 } \\
\hline$<142$ & 3 & 2.9 \\
\hline $142-424$ & 85 & 81.0 \\
\hline$>424$ & 17 & 16.2 \\
\hline
\end{tabular}

infected, of which 417 were hospitalized and treated and 21 developed mortality associated with HAV infection (13).

Although no sex difference is expected in HAV infection, some studies have reported that it is seen more in males (6, 7). Similarly in the current study, there was determined to be a slight male dominance (54.3\%). Most patients in the current study were of school-age, which was consistent with the findings of previous studies (6-10). That the vast majority of cases were school-age children confirms that the most important predisposing factors could be communal living areas, large families, and insufficient hygiene conditions. Mean age of the patients was found to be $6.9 \pm 3.5$ years in studies by Fousssal et al. (14) and Taşkesen et al. (9), and $7.8 \pm 3.4$ years by Devrim et al. (6). Mean age of the patients in the current study was found to be similar at $6.7 \pm 3.4$ years.
In this study, 3 (7.5\%) Turkish patients and 37 (35.2\%) Syrian refugees patients were identified in the 1-5 age group. The low number of cases in Turkish patients indicates that the Hepatitis A vaccination performed in the Sanliurfa region under the National Vaccination Program is effective. The high number of cases in Syrian refugees patients shows that hepatitis $A$ vaccination is inadequate.

Out of the 56 cases (53\%) in the 6-11 age group, 30 were Syrian refugees and 26 were Turkish patients. No statistically significant difference was found between the Syrian refugees and Turkish patients. The high number of cases in the 6-11 age group is thought to be due to the fact that these children were born before the Hepatitis A vaccine was introduced in the National Vaccination Program. 
Table 4. Comparisons of the hematological disorders determined in the patients with findings in literature

\begin{tabular}{|c|c|c|c|c|c|c|c|}
\hline & \multicolumn{7}{|c|}{ Hematological Disorders (\%) } \\
\hline & Taşkesen et al. (9) & Yasa et al. (19) & Akarsu et al. (22) & $\begin{array}{c}\text { Venkataravanamma } \\
\text { et al. (23) }\end{array}$ & Kanra et al. (24) & Uluğ et al. (18) & Our study \\
\hline Leukopenia & - & 9.5 & 0.9 & 7.4 & 9.5 & 2.0 & 1.9 \\
\hline Leukocytosis & - & - & 20.8 & 10.8 & - & 10.0 & 22.9 \\
\hline Neutropenia & - & - & 6.2 & - & - & 5.8 & 5.0 \\
\hline Anemia & 26.1 & 9.5 & 15.5 & 12.6 & 9.5 & 14.1 & 3.8 \\
\hline Thrombocytopenia & 7.1 & 11.3 & 4.3 & 19.3 & 11.3 & 5.8 & 2.9 \\
\hline Thrombocytosis & - & - & 11.5 & - & - & 7.8 & 16.2 \\
\hline Pancytopenia & - & - & - & 0.9 & - & - & - \\
\hline Total & - & - & 59.3 & - & 30.3 & 43.1 & 42.5 \\
\hline
\end{tabular}

It was observed that 7 out of the 9 cases in the 12-17 age group were Turkish patients and 2 were Syrian refugees patients. The low number of cases in this age group indicates that hepatitis $\mathrm{A}$ infection was experienced at an earlier age.

Michaelis et al. (15) reported an outbreak of HAV infection in refugees in Germany between September 2015 and March 2016. It was reported that refugee children and adolescents were at particular risk of HAV infection. Turkey shows a varying structure in respect of hepatitis A epidemiology as extremely large numbers of refugees and migrants have been taken in from neighboring countries. Thus, approximately two-thirds of the current study cases were Syrian refugees. That HAV infection is seen more frequently in Syrian refugees suggests that it could be associated with inadequate hygiene conditions, crowded living spaces, low socio-economic level and insufficient vaccinations (16-18). Consistent with previous findings in the literature $(6,7,9,18)$, HAV cases in this study were seen mostly in the winter and autumn months.

The diagnosis of acute viral hepatitis $A$ is based on history, physical examination and laboratory findings. Anti-HAV IgM positivity in the serum confirms diagnosis. In the current study, all patients had serum anti-HAV IgM positivity and $97 \%$ had anti-HAV IgG positivity. Although the symptoms and findings of patients are not specific, laboratory test results are generally determinant. In a study by Yasa et al. (19), the complaints on presentation have been reported as jaundice (82.7\%), listlessness (57.7\%), abdominal pain (52.5\%), loss of appetite (45.9\%) and dark color of urine (40\%). Taşkesen et al. (9) have reported complaints and rates as jaundice (73.8\%), vomiting (52.3\%), fever (42.8\%), abdominal pain (38.1\%), and listlessness $(26.1 \%)$. In the current series, the primary complaints on presentation were also determined as jaundice, listlessness, anorexia, nausea, loss of appetite, and dark color of urine. Although there are differences in the frequency of the complaints on presentation, the current study findings were observed to be similar to those of previous studies.
Generally, partial leukocyte count is normal or slightly low and there is a relative increase in lymphocyte count. Hemoglobin and hematocrit levels are normal, and minor clotting disorder and decreased fibrinogen may be seen (18). In the current study, there was observed to be a decrease in WBC in three-quarters of the cases, and in thrombocyte count in a small proportion (2.9\%) corresponding to normal hemoglobin levels in $90 \%$. The most striking biochemical finding was the evident elevation in serum transaminase levels. Elevated transaminase levels are an important sign of hepatocellular damage.

Serum ALP, GGT and total bilirubin values may be increased. Although serum albumin level is generally normal in acute HAV infection, it may occasionally be low. Prolonged PT is not often seen, but is a finding of severe liver synthesis disorder and may be a precursor of fulminating hepatitis $(8,20,21)$. Consistent with these findings in the literature, an increase was observed in the serum transaminase levels, ALP, GGT and total bilirubin values in all patients in the current study. In approximately two-thirds of the cases, albumin and/or total protein was determined to be low. Fouad et al. (7) have reported similar results in Egyptian children with similar characteristics to the current study cases. Although low albumin and total protein levels are primarily associated with liver inflammation, as the majority of the current study patients were Syrian refugees, they were thought to be associated with low socio-economic levels and malnutrition. During HAV infection, leukocytosis, leukopenia, anemia and thrombocytopenia may be seen $(8,19,22-24)$. In the current study patients, hematological disorders were seen including leukocytosis (22.9\%), leukopenia (1.9\%), anemia (3.8\%) and thrombocytopenia (2.9\%) (Table 4).

HAV infection continues to be a significant health problem because it leads to hospitalization, high costs, loss of workforce and complications. Prolonged PT-INR values can be seen during HAV infection (10). In cases determined with coagulopathy, there is a high risk of developing acute liver failure 
$(8,10,25)$, and it may develop in $<1 \%$ of cases during HAV infection (2). In 4 of the current study cases with excessively prolonged PT-INR, acute liver failure developed and these cases were transferred to the liver transplantation center. Of these cases that developed acute liver failure, 3 were Turkish citizens, and had been born before hepatitis A vaccination was included in the national vaccination program. The other patient was a 17-year old Syrian refugee. This result demonstrates that it is extremely important to closely monitor cases of acute viral hepatitis $A$ in respect of the development of acute liver failure. It has been reported that of the cases of acute liver failure seen in children living in HAV infection endemic regions, $40 \%$ are associated with HAV infection (1). Kayaalp et al. (26) have followed up 308 patients diagnosed with acute liver failure and reported that this was associated with hepatitis $A$ in $20.9 \%$. In a study by Özcay et al. (27), it has been reported that in 23 of 91 children followed up because of acute liver failure, it had developed as a result of hepatitis A infection. Çetinkaya et al. (10) have reported liver transplantation performed in 1 patient who developed acute liver failure. Kumar et al. (8) have reported a mortality rate of $1.3 \%$ in a study where acute liver failure resulted in death in 1 patient. In another study by Uluğ et al. (18), mortality rate has been reported as $0.8 \%$ with the deaths of 2 of 3 patients who developed acute liver failure. In the current study, of the 4 patients who developed acute liver failure, 3 recovered with supportive treatment and 1 was exitus. Although HAV infection is thought to have a mild course in children aged $<6$ years, a not insignificant rate of complications and fulminating cases may be seen. Morbidity and mortality rates can be greatly decreased with early diagnosis, treatment and transfer to centers where liver transplantation can be made for fulminating cases (28).

In 1 of the 3 current study cases who developed acute liver failure, autoimmune hepatitis developed during the follow-up period after recovery with supportive treatments. HAV infection can lead to the earlier emergence of autoimmune hepatitis, which is occasionally seen in sensitive cases (29). In addition, clinical findings other than in the liver may be seen during the course of HAV infection. In the current series, gallbladder hydrops developed in $2(1.9 \%)$ patients, and reactive arthritis in 1 patient. Similar studies in literature have reported different clinical findings.

In a study by Yasa et al. (19), skin rash (1.7\%), acid (1.7\%), acute glomerulonephritis and fluid accumulation in the pleura $(0.6 \%)$ have been reported. Taşkesen et al. (9) have reported liver coma $(9.5 \%)$, acid and fluid accumulation in the pleura (2.4\%). In a study by Kamath et al. (30), bleeding in the digestive system, intracranial bleeding (5.8\%), hypoglycemia $(0.7 \%)$ and coma (1.4\%) have been observed, and Uluğ et al. (18) have reported skin rash (1.3\%), acute glomerulonephritis $(0.4 \%)$ and fluid accumulation in the pleura (0.4\%).
Almost half of the current study patients were hospitalized for treatment for median $3.73 \pm 1.58$ days. In a study by Taşkesen et al. (9) in Diyarbakir, the length of stay in hospital because of acute viral hepatitis A has been reported to be 7.7 \pm 5.2 days. In a study of patients followed up with a diagnosis of acute viral hepatitis A in Izmir, Devrim et al. (6) have reported the median length of hospital stay as 4 days, whereas Çetinkaya et al. (10) have reported a mean stay of $5.2 \pm 4.5$ days. The length of stay in hospital because of a diagnosis of acute viral hepatitis $A$ can differ according to regions and the severity of the infection.

The inclusion of hepatitis A vaccination to the routine vaccination program in hyperendemic regions, such as Turkey, has significantly reduced the numbers of acute viral hepatitis $A$ cases. However, migration in recent years has led to a significant increase in new HAV epidemics. It is vital that refugees and immigrants are evaluated in respect of their immunity to infections which can be prevented with vaccinations in the countries where they settle and that missing vaccinations are completed. In addition, improvements in hygiene and sanitation conditions and the provision of information on this subject will further reduce the frequency of acute viral hepatitis A infection.

Ethics Committe Approval: The approval for this study was obtained from Furat University Non-Interventional Research Ethics Committee (Decision no: 07-13, Date: 05.04.2018).

Informed Consent: Patient informed consent was not obtained because it was a retrospective study

Peer-review: Externally peer-reviewed.

Author Contributions: Concept - UD, UA; Design - UA; Supervision - UD, ES; Resource - UD, UA; Data Collection and/or Processing - UD, ES; Analysis and/or Interpretation - UD, UA; Literature Search - UA, ES; Writing - UD, UA; Critical Review - UA.

Conflict of Interest: Authors declared no conflict of interest. Financial Disclosure: The authors declared that this study has received no financial support.

\section{References}

1. Yazigi N, Balistreri WF. Viral hepatitis. In: Kliegman RM, Stanton BF, St. Geme JW, Schor NF, Behrman RE (eds). Nelson Textbook of Pediatrics. $19^{\text {th }}$ ed. Philadelphia: Saunders; 2011, 1393-404. [CrossRef]

2. World Health Organization (WHO). Hepatitis A fact sheet. In: World Health Organization: media centre Available from: http://www.who. int/mediacentre/ factsheets/fs328/en/ Accessed date: 10 March 2017. [CrossRef]

3. Ince OT, Yalçin SS, Yurdakök K, Ozmert EN. Hepatitis A seroprevalence among infants aged 12 months in Ankara. Turk J Pediatr 2011;53:1146. [CrossRef]

4. Kurugol Z, Aslan A, Turkoglu E, Koturoglu G. Changing epidemiology of hepatitis A infection in Izmir, Turkey. Vaccine 2011;29:6259-61. [CrossRef] 
5. Richardus $J H$, Vos D, Veldhuijzen IK, Groen J. Seroprevalence of hepatitis $A$ virus antibodies in Turkish and Moroccan children in Rotterdam. $J$ Med Virol 2004;72:197-202. [CrossRef]

6. Devrim I, Memur Ş, Ziviş Z, Soylu Ö, Günay I, Dizdarer C, et al. The evaluation of the children with diagnosis of acute viral hepatitis A.J Pediatr Inf 2011;5:4-6. [CrossRef]

7. Fouad HM, Reyad EM, El-Din AG. Acute hepatitis A is the chief etiology of acute hepatitis in Egyptian children: a single-center study. Eur J Clin Microbiol Infect Dis 2018;37:1941-7. [CrossRef]

8. Kumar KJ, Kumar HC, Manjunath VG, Anitha C, Mamatha S. Hepatitis A in children-clinical course, complications and laboratory profile. Indian J Pediatr 2014;81:15-9. [CrossRef]

9. Taşkesen M, Taş MA, Ecer S, Özel A, Karabiberoğlu S. Evaluating of clinical and laboratory findings of patients with acute viral hepatitis A. Dicle Tip Derg 2008;35:155-8. [CrossRef]

10. Çetinkaya B, Tezer H, Özkaya Parlakay A, Revide Sayli T. Evaluation of pediatric patients with hepatitis A. J Infect Dev Ctries 2014;8:326-30. [CrossRef]

11. Chu J, Arnon R. Other Viral Infections. In: Kleinman RE, Goluet OJ, Meile-Vergani G, Sanderson IR, Sherman PM, Shneider BL. Walker's Pediatrics Gastrointestinal Disease. $6^{\text {th }}$ ed. Raleigh, North Carolina: People's Medical Publishing House; 2018, 1291-302. [CrossRef]

12. Squires RH Jr, Shneider BL, Bucuvalas J, Alonso E, Sokol RJ, Norkewicz $M R$ et al. Acute liver failure in children: the first 348 patients in the pediatric acute liver study group. J Pediatr 2006;148:652-8. [CrossRef]

13. California Department of Public Health. Hepatitis A Immunization. Available from: https://www.cdph.ca.gov/Programs/CID/DCDC/Pages/Immunization/Hepatitis-A-outbreak.aspx Accessed date: December 07, 2017. [CrossRef]

14. Foussal MD, Picón C, Sorrentino A. Hepatitis A in childhood. The tip of an infectious disease iceberg. Acta Gastroenterol Latinoam 2002;32:101-5. [CrossRef]

15. Michaelis K, Wenzel JJ, Stark K, Faber M. Hepatitis A virus infections and outbreaks in asylum seekers arriving to Germany, September 2015 to March 2016. Emerg Microbes Infect 2017;26:e26. [CrossRef]

16. Leung AKC, Kellner JD, Davies HD. Hepatitis A: a preventable threat. Adv Ther 2005;22:578-86. [CrossRef]

17. United Nations High Commission on Refugees. Syrian Regional Refugee Response 2018. Available from: https://www.data2.unhcr.org/en7situations/syria. Accessed date: $2018 \mathrm{Jul} 25$. [CrossRef]
18. Uluğ M, Yaman Y, Yapıcı Y, Uluğ NC. The investigation of acute viral hepatitis $A$ and its complications in childhood. J Pediatr Inf 2010;4:65-70. [CrossRef]

19. Yasa O, Dursun F, Fedakar A, Ergüven M. Acute hepatit A infection in childhood and extrahepatic complications. J Child 2005;5:48-50. [CrossRef]

20. Battegay MB, Gust ID, Feinstone SM. Hepatitis A virus. In: Mandell GL, Bennett JE, Dolin R (eds). Principles and Practice of Infectious Diseases. $4^{\text {th }}$ ed. New York: Churchill Livingstone; 1995, 1636-56. [CrossRef]

21. Ciocca M. Clinical course and consequences of hepatitis $A$ infection. Vaccine 2000;18(Suppl 1):S71-4. [CrossRef]

22. Akarsu S, Erensoy A, Elkıran Ö, Kurt A, Çıtak-Kurt AN, Aygün AD. Hematological abnormalities in patients with acute viral hepatitis $A$ and $B$. J Pediatr Inf 2008;3:90-5. [CrossRef]

23. Venkataravanamma $P$, Rau AT. Severe thrombocytopenia in association with hepatitis A. Indian Pediatr 2004;41:1178-9. [CrossRef]

24. Kanra G, Tezcan S, Badur S; Turkish National Study Team. Hepatitis A seroprevalance in a random sample of Turkish population by simultaneous EPI cluster and comparison with surveys in Turkey. Turk J Pediatr 2002:44:204-10. [CrossRef]

25. Srivastava A, Yachha SK, Poddar U. Predictors of outcome in children with acute viral hepatitis and coagulopathy. J Viral Hepat 2012;19:e194201. [CrossRef]

26. Kayaalp C, Ersan V, Yılmaz S. Acute liver failure in Turkey: A systematic review. Turk J Gastroenterol 2014;25:35-40. [CrossRef]

27. Özçay F, Karadağ-Öncel E, Barış Z, Canan O, Moray G, Haberal M. Etiologies, outcomes, and prognostic factors of pediatric acute liver failure: $A$ single center's experience in Turkey. Turk J Gastroenterol 2016;27:450-7. [CrossRef]

28. Sundaram V, Shneider BL, Dhawan A, Ng VL, Im K, Belle S et al. King's College Hospital Criteria for non-acetaminophen induced acute liver failure in an international cohort of children. J Pediatr 2013;162:31923.[CrossRef]

29. Skoog SM, Rivard RE, Batts KP, Smith Cl. Autoimmune hepatitis preceded by acute hepatitis A infection. Am J Gastroenterol 2002;97:1568-9. [CrossRef]

30. Kamath SR, Sathiyasekaran M, Raja TE, Sudha L. Profile of viral hepatitis A in Chennai. Indian Pediatr 2009;46:642-3.[CrossRef] 